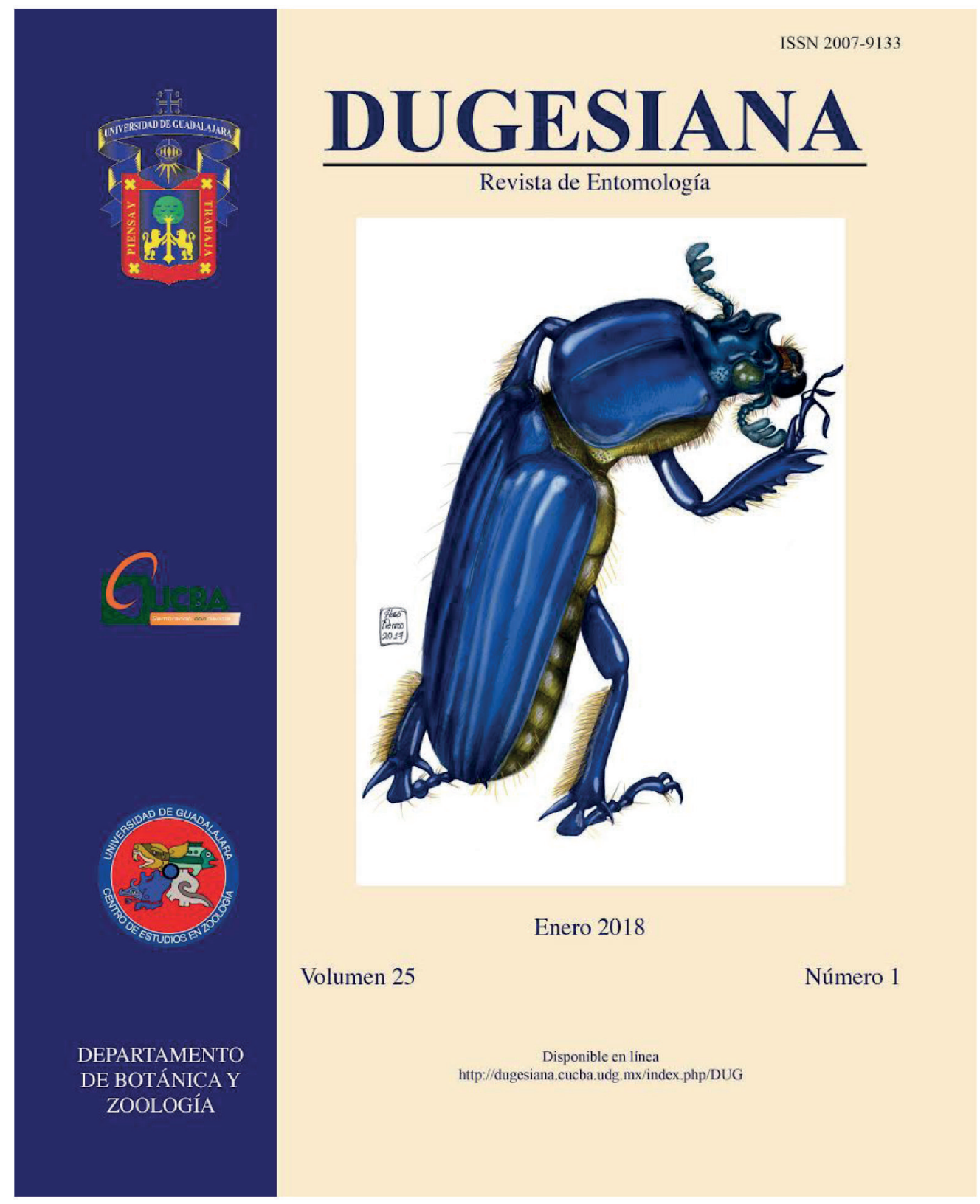

Dugesiana, Año 25, No. 1, enero 2018-junio 2018 (primer semestre de 2018), es una publicación Semestral, editada por la Universidad de Guadalajara, a través del Centro de Estudios en Zoología, por el Centro Universitario de Ciencias Biológicas y Agropecuarias. Camino Ramón Padilla Sánchez \# 2100, Nextipac, Zapopan, Jalisco, Tel. 37771150 ext. 33218, http://dugesiana.cucba.udg.mx/index.php/DUG, jose.navarrete@academicos.udg.mx. Editor responsable: José Luis Navarrete Heredia. Reserva de Derechos al Uso Exclusivo 04-2009-062310115100203, ISSN: 2007-9133, otorgados por el Instituto Nacional del Derecho de Autor. Responsable de la última actualización de este número: José Luis Navarrete Heredia, Editor y Ana Laura González-Hernández, Asistente Editorial. Fecha de la última modificación 1 de enero de 2018, con un tiraje de un ejemplar.

Las opiniones expresadas por los autores no necesariamente reflejan la postura del editor de la publicación.

Queda estrictamente prohibida la reproducción total o parcial de los contenidos e imágenes de la publicación sin previa autorización de la Universidad de Guadalajara. 


\title{
Record of Scolopendra viridis Say, 1821 (Chilopoda: Scolopendromorpha: Scolopendridae) from Banco Chinchorro Biosphere Reserve, Quintana Roo, Mexico
}

\section{Registro de Scolopendra viridis Say, 1821 (Chilopoda: Scolopendromorpha: Scolopendridae) en la Reserva de la Biosfera Banco Chinchorro, Quintana Roo, México}

\author{
Roxanne Gagnon ${ }^{1}$, Fabienne Dupuis ${ }^{1}$, Pierre Charruau ${ }^{2 *}$
}

\begin{abstract}
${ }^{1}$ Faculté des Sciences, Département de biologie, Université de Sherbrooke, 2500 Boulevard de l'Université, Sherbrooke, Québec J1K 2R1, Canada; ${ }^{2}$ Centro del Cambio Global y la Sustentabilidad en el Sureste, A.C., Calle Centenario del Instituto Juárez s/n, C.P. 86080, Colonia Reforma, Villahermosa, Tabasco, México. ${ }^{*}$ Corresponding author: charruau_pierre@yahoo.fr
\end{abstract}

The centipedes are terrestrial invertebrates and are part of the ground's biodiversity. These carnivorous arthropods live in tropical, subtropical, and temperate regions. More specifically we can encounter them in deserts, caves, coastal areas, jungles, forests, and under rocks (Shelley 2002, Bonato and Zapparoli 2011, Minelli 2011, Voigtländer 2011). These myriapods are distributed according to an important abiotic factor which is the humidity (Voigtländer 2011). This is the reason why we observe them more frequently overnight and during the rainy season (CupulMagaña 2013).

We acknowledge five extant orders of chilopods in the whole world: Scutigeromorpha, Lithobiomorpha, Scolopendromorpha, Geophilomorpha, and Craterostigmomorpha (Edgecombe and Giribet 2007). The last one is the only one who is not part of Mexico's fauna (Cupul-Magaña 2013). In this country, Scolopendromorpha contains 41 species and 13 of them belong to the genus Scolopendra L., 1758 (Cupul-Magaña 2007, 2014).

Scolopendra viridis Say, 1821 is a non-endemic species of Mexico. It is a nocturnal predator feeding mainly on other arthropods (Shelley 2002, Cupul-Magaña 2007, 2013). Those reaching around 30 centimeters can also feed themselves with amphibians, reptiles, birds and mammals, such as bats. In return, they are the prey of birds and terrestrial mammals (Cupul-Magaña 2007, 2013, 2014). During confrontations $S$. viridis shows a defensive behavior of avoidance (Shelley 2002, Cupul-Magaña 2007).

Scolopendra viridis, as well as $S$. polymorpha, $S$. morsitans, and Arthrorhabdus pygmaeus, is one of the most encountered species of the Scolopendridae family in Mexico (Cupul-Magaña 2013). Even if cases of bites are rarely reported, $S$. viridis is venomous, giving to the species a medical interest (Cupul-Magaña 2007, 2013). Although they are dangerous for humans, the centipedes limit populations of arthropods by their general consume of preys. This is a profitable behavior because these invertebrates can be noxious for humans and other species (Cupul-Magaña 2013).

In the literature, $S$. viridis has one of the most complete and known distribution for Mexico (Cupul-Magaña 2014). Here is the second record for $S$. viridis in Quintana Roo, Mexico, and the first in Banco Chinchorro Biosphere Reserve, an atoll located $35 \mathrm{~km}$ off the coast of the Quintana
Roo state.

\section{Scolopendra viridis Say, 1821}

Previous records : Costa Rica, El Salvador, Guatemala, Honduras, Mexico, Nicaragua, Panama, and United States of America. In Mexico : Baja California, Baja California Sur, Chiapas, Chihuahua, Coahuila, Colima, Ciudad de México, Durango, Estado de México, Guanajuato, Guerrero, Hidalgo, Jalisco, Michoacán, Morelos, Nayarit, Nuevo León, Oaxaca, Puebla, Querétaro, Quintana Roo, San Luis Potosí, Sinaloa, Sonora, Tamaulipas, Veracruz, and Zacatecas (Vázquez González 1997, Cupul-Magaña 2007, 2010, 2012, 2013, Lucio-Palacio 2010).

Material examined: Cayo Centro, Reserva de la Biosfera Banco Chinchorro (RBBCH), Quintana Roo,

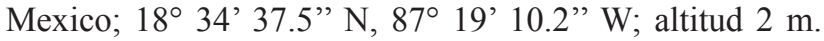
Two adult samples, sex non-determined. Size (length including the last pair of legs -width measured at the twelfth tergite): $101.3 \mathrm{~mm}-6.7 \mathrm{~mm}, 100.5 \mathrm{~mm}-7.2 \mathrm{~mm}$. 18-Aug2016; col. P. Charruau. The first specimen was found in the litter of an American crocodile (Crocodylus acutus) nest and the second was found in the litter of a coastal bush. Both specimen have been deposited to the collection of the Museo de Zoología, El Colegio de la Frontera Sur, Unidad Chetumal (ECO-CH-AR), Quintana Roo. This record is the first for islands of Quintana Roo and is located ca. $137 \mathrm{~km}$ SE from the first record for this State near Felipe Carrillo Puerto (Vázquez González 1997).

Scolopendra viridis show considerable color variation (Shelley 2002). Our specimen showed a wide range of green and blue colors. Here is the description of their coloration after preservation in ethyl alcohol $96 \%$, based on Köhler (2012). Antennae: Cyan black. Forcipules: Amber. Cephalic plate: Greenish Olive. Dorsal part (Tergites): Olive-Green; Greenish Olive. Side part (Pleurites): Pratt's Payne's Gray; Light Sky Blue. Ventral part except Twentyfirst segment (Sternites): Olive Horn Color; Raw Umber. Twenty-first segment's ventral part (Sternite): Olive-Green; Hair Brown. Coxopleural part of Twenty-first segment: Tawny. Locomotive legs (First to twentieth pairs of legs): Tawny Olive; Clay Color. Last pair of legs: from OliveGreen to Cyan black; Glaucous (Dorsal view), Pratt's Payne's Gray (Ventral view). 
Morphological description: The criteria from the identification keys of Shelley (2002) and Cupul-Magaña (2012) used to identify both samples are the following: 21 pairs of legs including the last legs (Fig. 1a,b), four ocelli each side of the head (Fig. 1f), triangular spiracles (segments 3, 5, 8, 10, 12, 14, 16, 18 and 20) (Fig. 1d), first tergite with a conspicuous transversal suture (Fig. 1f), cephalic plate without longitudinal sutures (Fig. 1f), and coxosternum without transverse suture. Furthermore, the prefemoral spines combinations of the individuals on the prefemoral process (Fig. 1g) correspond to the most frequent combination for the species $(2 / 2 ; 2 / 3)$ (Shelley 2002).

According to Shelley (2002), S. viridis presents a middorsal suture on the ultimate tergite but this was not observed on our specimens and this characteristic apparently vary among individuals (Shelley 2002). Another divergence observed from our specimen is concerning antennae's segments. Unlike the keys used for the identification (Shelley 2002, Cupul-Magaña 2012) saying that segments fourth to seventh are hairy - all fourth to twenty seventh segments of the antennae are recovered with setae (Fig. 1e). Shelley (2002) also mentioned this characteristic as variable among individuals. After the observation of our samples, we concluded that the antennae are subdivided in 27 segments. Given those facts and because the number of antenna segments varies between 21 and 31 in the literature for S. viridis (Attems 1930, Lewis 2016), antennal characters cannot be considered as a main characteristic for species determination.

\section{LITERATURE CITED}

Attems, G. 1930. Myriapoda 2. Scolopendromorpha. Das Tierreich 54. Walter de Gruyter \& Co., Berlin, Leipzig.

Bonato, L. and M. Zapparoli. 2011. Chilopoda - Geographical distribution. (pp. 327-337). In: Minelli, A. (Ed.). The Myriapoda: Treatise on Zoology - Anatomy, Taxonomy, Biology, Volume 1. Brill, Leiden.

Cupul-Magaña, F. G. 2007. Scolopendra viridis Say 1821. Dugesiana, 14(2): 53-57.

Cupul-Magaña, F. G. 2010. An annotated list of the centipedes (Chilopoda) in the National Collection of Arachnids, Instituto de Biología, Universidad Nacional Autónoma de México. Insecta Mundi, (125): 1-10.

Recibido: 21 de junio 2017

Aceptado: 18 de agosto 2017
Cupul-Magaña, F. G. 2012. Los ciempiés escutigeromorfos (Scutigeromorpha), escolopendromorfos (Scolopendromorpha) y geofilomorfos (Geophilomorpha) de la selva tropical caducifolia de la reserva de Chamela, Jalisco, México. Insecta Mundi, (0208): 1-17.

Cupul-Magaña, F. G. 2013. La diversidad de los ciempiés (Chilopoda) de México. Dugesiana, 20(1): 17-41.

Cupul-Magaña, F. G. 2014. Los ciempiés escolopendromorfos (Chilopoda: Scolopendromorpha) de México: clave para géneros. Revista Colombiana de Entomología, 40(2): 286-291.

Edgecombe, G. D. and G. Giribet. 2007. Evolutionary biology of centipedes (Myriapoda: Chilopoda). Annual Review of Entomology, 52: 151-170.

Köhler, G. 2012. Color catalogue for field biologists. Bilingual edition English/Spanish. Herpeton, Offenbach.

Lewis, J. G. E. 2016. On the consistency of some taxonomic characters in the Scolopendromorpha and comments on the scolopocryptopid subfamily Kethopinae (Myriapoda: Chilopoda). Acta Societatis Zoologicae Bohemicae, 80(1): 21-31.

Lucio-Palacio, C. R. 2010. Primer registro de Scolopendra viridis Say 1821 (Myriapoda: Scolopendromorpha) para Aguascalientes, México. Dugesiana, 17(2): 147148.

Minelli, A. 2011. The Chilopoda - Introduction: diagnosis. (pp. 21). In: Minelli, A. (Ed.). The Myriapoda: Treatise on Zoology - Anatomy, Taxonomy, Biology, Volume 1. Brill, Leiden.

Shelley, R.M. 2002. A sinopsis of the North American centipedes of the order Scolopendromorpha (Chilopoda). Virginia Museum of Natural History, (5): 1-108.

Vázquez González, M. M. 1997. Estudio de la fauna edáfica en una selva baja inundable de la Reserva de la biósfera de Sian Ka'an Quintana Roo. Universidad de Quintana Roo. Bases de datos SNIB-CONABIO proyecto No. B051. México, D.F. http://www.snib.mx/ iptconabio/resource? $r=$ SNIB-B051-B051906F-ND

Voigtländer, K. 2011. Chilopoda - Ecology. (pp. 309325). In: Minelli, A. (Ed.). The Myriapoda: Treatise on Zoology - Anatomy, Taxonomy, Biology, Volume 1. Brill, Leiden. 

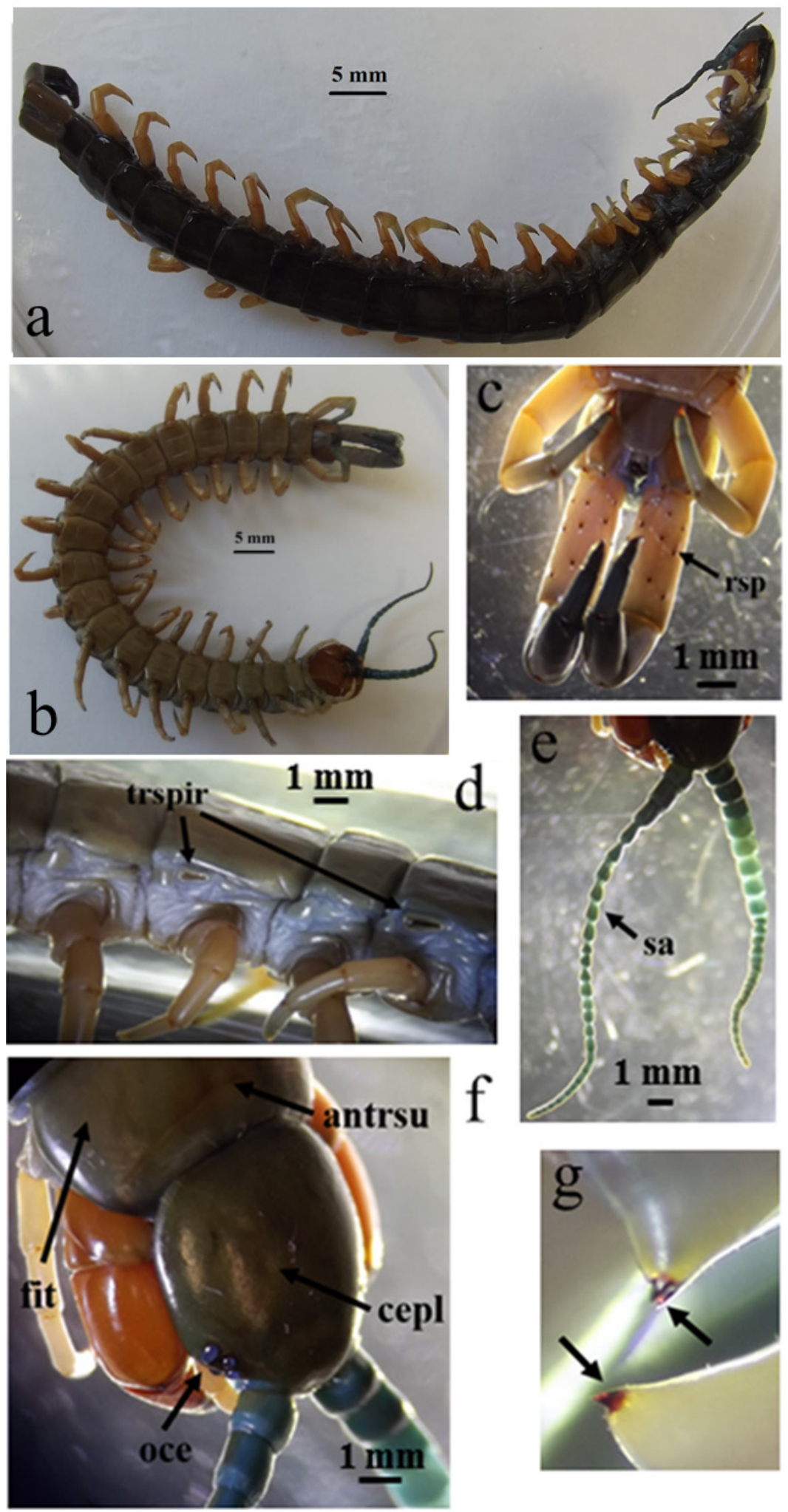

Figure 1: a-b) Dorsal and ventral views of the specimen of Scolopendra viridis collected at Banco Chinchorro; c) ventral view of the last pair of legs and of a part of the last tergite: rsp= rows of spines; d) lateral view of the third to the sixth tergites (right to left): trspir= triangular spiracles; e) dorsal view of a part of the cephalic plate and of the antennae. We can count 27 segments on the antennae placed at the left on the figure: $s a=$ segments of the antennae; f) dorsal view of the cephalic plate and of the first tergite: fit = first tergite, cepl= cephalic plate, antrsu $=$ anterior transversal suture, oce $=$ ocelli; g) details of the prefemoral spines on the prefemoral processes. 